\title{
Ethnic Conflict, War Crimes and Human Rights: Revisiting U.S Sponsored UNHRC Resolution against Sri Lanka in 2013
}

\author{
S. M. ALIFF \\ Senior Lecturer, Dept of Social Sciences, Faculty of Arts \& Culture \\ South Eastern University of Sri Lanka, Oluvil, Sri Lanka. \\ E-mail address: smaliff@seu.ac.lk
}

Keywords: Ethnic Conflict; War Crimes; Human Rights

\begin{abstract}
The civil war ended in 2009 but four years later the country has yet to find its path of reconciliation and to heal the wounds of war. At the present time it also appears that Sri Lanka is moving backwards, and not forwards, in terms of securing the rule of law and reconciliation. This has impacted negatively on the rule of law and by extension the protection of human rights and political accountability. There is also the rise of inter-religious tensions fanned by government allies. A new dimension of inter-communal unrest is the rise of Buddhist extremism in some quarters; it has targeted the Muslim community and taken on an open and frontal confrontational approach.

One of the main elements of external intervention in the internal affairs of post-war Sri Lanka is the continuing pressure being brought to bear on the government to adopt a system of provincebased devolution as one of the instrumentalities of ethnic reconciliation. It is, indeed, unfortunate that the LLRC itself has made a similar prescription. There is no evidence in the voluminous report produced by the Commission that it made any attempt to draw 'lessons' relevant to the subject of territorial devolution and sub-national inter-group conflict from our own experiences, leave alone the abundance of international experiences. Its recommendation, however, has had the effect of legitimizing the demand made by the global west which, in earlier times, was so obviously based on a nakedly superficial, local NGO-nurtured, understanding of Sri Lankan affairs.
\end{abstract}

\section{INTRODUCTION}

Sri Lanka gained independence from Britain in 1948 after almost 450 years of colonial rule by various western powers. In post-independence era, number of attempts had been made to establish a Sinhala - Buddhist hegemony and antagonism against minority groups. As a result of SinhalaBuddhist consciousness, it was resulted in the denial of the multi-ethnic and multi-religious character of Sri Lankan society and in refusal to accept the collective rights of other minority groups. This consciousness was further counterpoised by its ideologies against the British imperial state, which was seen as foreign and Christian; the revival was thus more anti-Western than antiimperialist, asserting a Sinhala Buddhist identity against all foreigners and minorities. ${ }^{1}$

In the Sri Lankan context, the history of ethnic conflict is the history of emergence of consciousness among the majority community which was defined the Sri Lanka society as Sinhala-Buddhist. This historical narration is in fact denying multi-ethnic character. The growth of this consciousness impinged on the minorities in Sri Lanka to the extent that internal resolutions of the problems become impossible. Support for numerous Tamil militant groups flourished and hundreds of thousands of Tamils emigrated in following few years, creating international support base for Tamil separatism that continues today. Liberation Tigers of Tamil Eelam (LTTE), fighting for separate Tamil state, emerged dominant by late 1980s after their violent elimination of Tamil rivals. The violent ethnic conflict that had ravaged Sri Lanka for three decade resulted massive human rights violations and many deaths.

\footnotetext{
${ }^{1}$ Jayawardena, Kumari - "The Rise of the Labour Movement in Ceylon", Durham, N.C., 1972. - "Ethnic and Class Conflicts in Sri Lanka", Colombo, 1986.
} 
Following the 2nd January 2009 capture of de-facto LTTE capital of Killinochchi, government forces won back all but small amount of territory held by LTTE in the Mullaitivu District. First four months of 2009 saw more than 300,000 civilians trapped in areas of fighting, with limited access to food, water or medical assistance. The LTTE forcibly conscripted civilians and prevented others from fleeing LTTE-controlled areas by firing at them, killing many. Government repeatedly bombed and shelled densely populated areas, including its own unilaterally declared "no fire zone". 13th March 2009 statement by UN High Commissioner for Human Rights expressed grave concern over credible evidence of war crimes by both sides. UN and government leaders called on the LTTE to allow civilians freedom of movement and urged both sides to halt their fighting to allow access for additional humanitarian relief and humanitarian personnel. The Government rejected any pause in the fighting. UN Agencies estimated more than 7,500 civilians dead and over 15,000 wounded between mid-January and early May 2009, but the death toll remains disputed, with government rejecting early June media reports that as many as 20,000 civilians killed in final weeks of war.

With the military phase of Sri Lanka's thirty-year civil war over, major challenges remain before a lasting peace can be found. The treatment of more than 280,000 civilians who escaped the fighting and were forced to remain in overcrowded government-run internment camps generated significant international concern and pressure on the government. Conditions in camps failed to meet international standards, with poor sanitation, insufficient water supplies and inadequate food and medical care. The displaced were denied the right to live with relatives or host families, and UN agencies and humanitarian organizations were denied full and unimpeded access to the camps and unable to deliver adequate supplies and services.

By October 2009 fewer than 20,000 had been released from the camps. Responding to international pressure and growing domestic unease, the government sped up resettlement process in the final months of 2009 , with nearly 150,000 released from the camps and allowed to return to their home districts by the end of the year. By the end of 2010, UN figures indicated that all but 20,000 had left the camps, though an additional 70,000 were forced to stay with host families, unable to return to their own land. ${ }^{2}$

The Sri Lankan security forces and the Liberation Tigers of Tamil Eelam (LTTE) repeatedly violated international humanitarian law during the last five months of their 30-year civil war. Although both sides committed atrocities throughout the many years of conflict, the scale and nature of violations particularly worsened from January 2009 to the government's declaration of victory in May 2009. Evidence gathered by the International Crisis Group suggests that these months saw tens of thousands of Tamil civilian men, women, children and the elderly killed, countless more wounded, and hundreds of thousands deprived of adequate food and medical care, resulting in more deaths. ${ }^{3}$

The Sri Lankan systematically excluded international aid workers and journalists from zone, so as to improve 'deniability'. However, the US embassy continued to gather detailed information regarding these conditions throughout this period from various sources; apart from which, of course, it had access to satellite images.

\section{US INTEREST IN SOUTH ASIA}

The US interest in the affairs of South Asia remained limited ${ }^{4}$. Active American involvement in Asia largely restricted to the Pacific Rim Countries, notably China, Japan and Philippines. Besides, the US was conditioned to think of South Asia as Great Brittani's defence responsibility. As Pervaiz Iqbal Cheema mentioned" the US policy towards South Asia was "inconsistent,

\footnotetext{
2/http://www.crisisgroup.org/en/publication-type/key-issues/research-resources/conflict-histories/sri-lanka.aspx. accessed on $11 / 5 / 13$

3 /http://www.crisisgroup.org/en/regions/asia/south-asia/sri-lanka/191-war-crimes-in-sri-lanka.aspx. accessed $11 / 05 / 2013$

${ }^{4}$ Jain: Rashmi, US-Pak Relations, 1947-83, Radian Pub, New Delhi, 1983.

${ }^{5}$ Pervaiz Iqbal Cheema, 'American Policy in South Asia: Interests and Objectives', in Stephen Cohan(ed), The Security of South Asia: American and Asian Perspectives, Vistaar Pub, New Delhi,1987.
} 
confused and reactive rather than calculated, long term, and innovative". Its policy fluctuated and this has to be comprehended in terms of the cold war situation prevailed between the Super Powers. In other words, its interest in the region has been a bi-product of the rivalry between the US and the Soviet Union. In the broad US policy objective, the South Asian region merited low priority ${ }^{6}$. However, the US maintained good relations with South Asian countries to prevent them from coming under the influence of other Super Power.

However, as communism triumphed in China In 1949, the US thinking of Asia was vitally affected. John Foster Dulles, the Secretary of State and the archetypal Cold War warrior was determined to hem in the communist expansion through a series of US- sponsored security facts in the world. The loss of China forcefully brought to the consciousness of US policy makers the importance of strengthening relation with the Indian sub-continent ${ }^{7}$.

After the Cold War the US emergence of the Lone Super Power gives to US an extra edge of hegemonic influence all over the world. Obviously, the policies and actions of the irresistible unipolar power have considerable impact on South Asia also. The United States has always considered situation in the subcontinent as detrimental to the US interests. This time the problem has gained added significance for the United States because it involves all that is prominent in America's post cold war South Asia policy - nonproliferation, human rights, terrorism and so forth. Now the US wishes to increase its presence in the Indian Ocean, and connect it with its Pacific forces:

Asia's remarkable economic growth over the past decade and its potential for continued growth in the future enhancing US presence in South Asia and into the Indian Ocean. US concern was how translates the growing connection between the Indian and Pacific oceans into an operational concept is a question that need to answer to adapt to new challenges in the region. Against this backdrop, a more broadly distributed military presence across the region will provide vital advantages. The United States will be better positioned to support humanitarian missions; equally important, working with more allies and partners will provide a more robust bulwark against threats or efforts to undermine regional peace and stability.

It is now becoming increasingly clears that U.S. Policies towards Sri Lanka are asymmetrical. The U.S. is applying heavy pressure toward the Sri Lanka government to accelerate the reconciliation process with the minority Tamil population after the war against LTTE in 2009, while ignoring the major strides that have been made towards this goal by the Sri Lankan government and people. At the same time, the U.S. seems to be paying little attention to the geo-strategic dimensions of U.S.Sri Lanka relations as well as to the economic potential that Sri Lanka has to offer as the fastest growing economy in its region and as a gateway to a one billion people market in next door India.

As we have seen, the US also provided significant assistance and encouragement to Rajapakse's offensive. During the last stage of the war in 2009, the US restricted itself to general appeals, but carefully avoided using language that would send a clear signal to Rajapakse Once the massacre was over, evidence of the massacre could serve as a handy instrument with which to bring about a strategic realignment of the Sri Lankan regime.

Of course, it may not be as smooth sailing for the US in Sri Lanka as in Burma. The Burmese regime lacked mass support, and it feared popular unrest; Sri Lanka's Rajapakse on the other hand has enjoyed till now significant mass support based on Sinhala chauvinist sentiment (indeed, he uses the fact of external pressure to bolster his domestic image as a defender of Sinhala interests). A further significant factor is that Sri Lanka's economic and political ties with the US are considerably broader than Burma's were.

The US, for its part, now changed its stance. It made increasingly critical noises as the conflict reached its final stages, demanding the protection of civilians and calling for international access to them. Obama issued his first statement on the issue on May 14, 2009, expressing concern regarding civilian casualties, and calling for Sri Lanka to conclude a peace that is "grounded in respect for all

\footnotetext{
${ }^{6}$ A.Subramayam Raju, Democracies at Loggerheads: Security Aspects of US- India Relations, South Asian Pub, New Delhi, 2001.

${ }^{7}$ Gupta,R.C., US Policy Towards India and Pakistan, B.R.Pub, New Delhi, 1977.
} 
of its citizens." "to assure all of Sri Lanka's communities a future of hope, respect and dignity."9

Thus the US began expressing concern about Sri Lankan war crimes more insistently only after the slaughter was over, and the LTTE was wiped out. Its real concern has little to do with human rights. Since 2005, particularly with Rajapakse's presidency, ties between the Sri Lankan regime and China have grown closer. US pressure on Sri Lanka has been stepped up since 2011, in this strategic drive to get control of Asia, the issue of "human rights" is to be an important weapon for the USA:

\section{CHINA FACTOR IN US- SRI LANKA RELATIONS}

In the recent past, China is following "string of pearls" policy. 'String of Pearls' is a nexus of Chinese geopolitical influence or military presence. Hainan Island, with recently upgraded military facilities, is a 'pearl'. An upgraded airstrip on Woody Island, located in the Paracel archipelago 300 nautical miles east of Vietnam, is a 'pearl'. A container shipping facility in Chittagong, Bangladesh, is a 'pearl'. Construction of a deep water port in Sittwe, Myanmar, is a 'pearl', as is the construction of a navy base in Gwadar, Pakistan. Port and airfield construction projects, diplomatic ties and force modernization form the essence of China's 'String of Pearls'. The 'pearls' extend from the coast of mainland China through the littorals of the South China Sea, the Strait of Malacca, across the Indian Ocean, and on to the littorals of the Arabian Sea and Persian Gulf. China is building strategic relationships and developing a capability to establish a forward presence along the sea lines of communication (SLOCs) that connect China to the Middle East. ${ }^{10}$

Sri Lanka is situated near strategically important sea lanes that transit the Indian Ocean. These sea lanes link the energy rich Persian Gulf with the economies of East Asia. The West's ability to pressure the Sri Lankan government was viewed as somewhat limited due to China's growing involvement in the country. ${ }^{11}$ China's aid to Sri Lanka has reportedly increased dramatically since 2005. In the view of some analysts and observers, China is seeking to gain influence with the Sri Lankan government as part of a "string of pearls" naval strategy to develop port access in the northern reaches of the Indian Ocean ${ }^{12}$. Indian defense planners are reportedly particularly concerned with Chinese efforts to develop ports in the region. India is home to an estimated 60 Million Tamil people and New Delhi has raised concerns over the treatment of Tamils in Sri Lanka. China is reportedly investing significantly in the development of a port in Hambantota, Sri Lanka, on the country's southeastern coast. China is also reportedly helping to develop port facilities in Gwadar, Pakistan; Chittagong, Bangladesh; and Sittwe, Burma ${ }^{13}$. Colombo was also reportedly upset with Western calls for a truce in the lead up to their defeat of the LTTE in May 2009.

Apart from providing weapons, China has also provided substantial economic aid and is constructing several large infrastructural projects. Most important are the massive port complex and airport at the southern town of Hambantota, from where Rajapakse hails. China has also secured deals for the country's largest rail and road projects. As a result, there are reportedly between 10,000 and 16,000 Chinese engineers, tradesmen and technical specialists at present working in Sri Lanka. Sri Lanka plans to open a direct air link with southern China's Yunnan province ${ }^{14}$.

\footnotetext{
${ }^{8} \mathrm{http}: / /$ www.reuters.com/article/2009/05/14/us-srilanka-idUSN1343603620090514 \{.Accessed on 25/3/2013\}

${ }^{9} \mathrm{http}: / / w w w . s t a t e . g o v / \mathrm{p} / \mathrm{sca} / \mathrm{rls} / \mathrm{rmks} / 2009 / 123745 . \mathrm{htm}$

10 "String of Pearls: Meeting the Challenge of China's Rising Power across the Asian Littoral", Christopher J. Pehrson, 2006, Strategic Studies Institute (US). http://www.strategicstudiesinstitute.army.mil/pdffiles/pub721.pdf \{Accessed on $30 / 3 / 2013$ \}

11 Sujan Dutta, “USA, India Engaging with Sri Lanka Amid Growing China Role,” BBC News, March 11, 2009. \{Accessed on $23 / 4 / 2013$ \}

${ }_{12}$ Michael Richardson, "Full Steam Ahead for Naval Might," The Straits Times, January 15, 2009.

13 “Chinese Billions Helping Lanka Ward Off Western Peace Efforts," Asian News International, May 2, 2009

14 "Another bead in the 'String of Pearls'? Interpreting Sri Lanka's Foreign Policy Realignment", Sergei De SilvaRanasinghe,China,Security,Issue19,2011,WorldSecurityInstitute,
} 
"Globally, China is increasingly active in striving for energy security in ways that portend direct competition for energy resources with the United States", claims the US-China Commission in its 2005 Report to the US Congress. "This is producing a possibility of conflict between the two nations." "The Commission's 2012 Report indicates how China's vulnerability can be exploited by the US: "China's leaders view China's growing dependence on foreign energy as a strategic vulnerability.... China also relies heavily on maritime trade routes for its energy imports, exposing China's energy trade to crucial chokepoints like the Strait of Malacca and the Strait of Hormuz." 16

Sri Lanka's strategic significance arises from its location. The Congressional Research Service notes that "Chinese activity in the region appears to be seeking friends like Sri Lanka to secure its sea lines of communication from the Straits of Hormuz and the western reaches of the Indian Ocean region to the Strait of Malacca to facilitate trade and secure China's energy imports.",17

The US military contractor Booz-Allen-Hamilton first coined the phrase "String of Pearls" to describe China's emerging maritime strategy, in a US Department of Defense-commissioned 2005 report "Energy Futures in Asia". The phrase has since been used freely by US and Indian strategic analysts as if it were an expression coined by China itself to describe its own strategy. "Even for those that dismiss China's 'string of pearls' strategy as overblown," says the Committee on Foreign Relations, "there is concern about growing Chinese influence on the Sri Lankan government."18

The stick may be more prominent at the moment in US dealings with Sri Lanka, but the carrot is not far behind. The Senate Committee on Foreign Relations, chaired by Kerry, warned in 2009 itself against an exclusive focus on Tamil refugees: "Sri Lanka has grown politically and economically isolated from the West. This strategic drift will have consequences for US interests in the region... Sri Lanka is located at the nexus of crucial maritime trading routes in the Indian Ocean connecting Europe and the Middle East to China and the rest of Asia.... The United States cannot afford to 'lose' Sri Lanka." Rather than be driven "solely by short-term humanitarian concerns", US policy should "Take a broader and more robust approach to Sri Lanka that appreciates new political and economic realities in Sri Lanka and US geostrategic interests." The report recommends, among other things, that the US Congress should "Authorize the US military to resume training of Sri Lankan military officials to help ensure that human rights concerns are integrated into future operations and to help build critical relationships."19

The plan for the US's cynical use of 'human rights' in this region has perhaps been set by developments in Burma. Burma has been under US sanctions since 1997 for its overturning of the election verdict, arrest of political opponents, and imposition of military rule. These sanctions by the US and its allies led the Burmese military rulers to strengthen ties with China, which became overwhelmingly the main foreign investor and source of financial aid, constructing a number of infrastructure projects. Particularly important among these is a Chinese-built port at Sittwe in the south, and a pipeline to carry oil to southern China - thus avoiding the choke-point of the Malacca Straits through which ships traveling to China must pass, and giving greater security to Chinese oil supplies. (The Chinese-built port at Gwadar, in Pakistan's Baluchistan province, is intended to serve

http://www.chinasecurity.us/index.php?option=com_content\&view=article \&id=492\&Itemid=8

$\{$.Accessed

on $29 / 4 / 2013\}$

15 Report to the Congress of the US-China Economic and Security Review Commission, 2005, p. 171, http://origin.www.uscc.gov/sites/default/files/annual_reports/2005-Report-to-Congress.pdf $\{$ Accessed on 28/3/2013\}

${ }_{16}$ Report to the Congress of the US-China Economic and Security Review Commission, 2012, p. 17, http://origin.www.uscc.gov/sites/default/files/annual_reports/2012-Report-to-Congress.pdf. Accessed on 26/3/2013

$17 \mathrm{Cited}$ in http://www.gpo.gov/fdsys/pkg/CPRT-111SPRT53866/html/CPRT-111SPRT53866.htm. Accessed on $27 / 3 / 2013$

18 "Another bead in the 'String of Pearls'? Interpreting Sri Lanka's Foreign Policy Realignment", Sergei De SilvaRanasinghe, China Security, Issue 19, 2011, World Security Institute,

http://www.chinasecurity.us/index.php?option=com_content\&view=article\&id=492\&Itemid=8. $\quad$ Accessed $1 / 4 / 2013\}$

${ }^{19} \mathrm{http}: / /$ www.gpo.gov/fdsys/pkg/CPRT-111SPRT53866/html/CPRT-111SPRT53866.htm. accessed on 23/3/2013 /http://asiantribune.com/news/2012/05/25/us-human-rights-report-2011-sri-lanka-lack-accountability-war-crimeshighlighted. $\{$ Accessed on 25/4/2013\} 
the same purpose.) Thus the Chinese have not only very large economic stakes in Burma, amounting to tens of billions of dollars, but vital strategic stakes as well. On the one hand, it is alarmed by Chinese influence in a region it considers its zone of influence.

When, in early 2007, Sri Lanka acquired a Chinese-built JY-11 3D radar system, India's National Security Adviser MK Narayanan protested it on the grounds that it would overarch Indian airspace: "It is high time that Sri Lanka understood that India is the big power in the region and ought to refrain from going to Pakistan or China for weapons, as we are prepared to accommodate them within the framework of our foreign policy," he said. ${ }^{20}$ [61] The implication was that Sri Lanka should come instead to India for weapons. In line with this, India voted in support of the Sri Lankan regime at the UN Human Rights Council in 2009. On the other hand, it appears that the US has now both applied sufficient pressure on, and promised sufficient rewards to, the Indian rulers for their cooperation in bringing about 'regime realignment' in Sri Lanka. Thus India, which had supported the Sri Lankan regime in the UNHRC in 2009, voted against it in 2012 and 2013.

The Sri Lankan Government says American attitudes and military restrictions led it to build relationships with China, Burma, Iran, and Libya. The Minister of Science and Technology and AllParty Representative Committee Chairman Tissa Vitarana Minister told committee staff, "We have the United States to thank for pushing us closer to China." According to Vitarana, President Rajapaksa was forced to reach out to other countries because the West refused to help Sri Lanka finish the war against the LTTE. These calculations - if left unchecked - threaten long-term U.S. strategic interests in the Indian Ocean. ${ }^{21}$

Recent U.S.-Sri Lanka relations have centered on human rights abuses committed at the end of the civil war between Sri Lankan government forces and LTTE fighters. The U.S. Permanent Representative to the United Nations, Ambassador Susan Rice, welcomed the U.N. Panel of Experts Report on Sri Lanka and stated that the U.S. supports: an effective, transparent post- conflict reconciliation process in Sri Lanka that includes accountability for violations by all parties. The report indicates the need for an independent and full accounting of the facts in order to ensure that all allegations of abuse are addressed and impunity for human rights violations is avoided ${ }^{22}$. U.S. Assistant Secretary of State for South and Central Asia Robert Blake, who was also previously U.S Ambassador to Sri Lanka, reportedly stated that the U.S. first looks to host governments to take responsibility for such issues but that "international mechanisms can become appropriate in cases where states are either unable or unwilling to meet their obligations."23

On the other hand, the U.S. Department of State has described U.S. development assistance priorities for Sri Lanka as seeking to increase human and economic security, improve public confidence in local and regional authorities, promote political reconciliation and land reform, facilitate community reintegration, uphold military and police professionalism and respect for human rights, and strengthen the Government of Sri Lanka's counterterrorism, port and border security, civilian authority, and demining capabilities. ${ }^{24}$

\section{LLRC and Human Rights}

The UN panel of experts has found credible allegations of war crimes by both the government and the LTTE and recommended the establishment of an independent mechanism to investigate war crimes in Sri Lanka in March 2011. ${ }^{25}$ The report found that most of the casualties in the final stages of the war were caused by government forces which shelled "no-fire zones" where they had urged civilians to congregate. The government also reportedly shelled hospitals and food distribution lines. The LTTE apparently used civilians as human shields and shot civilians trying to escape

\footnotetext{
20 "Another bead in the 'String of Pearls'?", op. cit.

${ }^{21} \mathrm{http}: / / w w w . g p o . g o v / f d s y s / p k g / C P R T-111$ SPRT53866/html/CPRT-111SPRT53866.htm . \{Accessed on 23/4/2013\}

${ }^{22}$ Ambassador Susan Rice, U.S. Permanent Representative to the United Nations, "Statement on the Release of the UN

23 "US Wants Sri Lanka to Act First on Wartime Rights Violations," Reuters, May 4, 2011.

${ }^{24}$ U.S. Department of State, Congressional Budget Justification for Foreign Operations, FY2012, Annex: Regional Perspectives

${ }^{25}$ Report of the Secretary-General's Panel of Experts on Accountability in Sri Lanka, March 31, 2011
} 
being used as a strategic human buffer in the fighting. At one point, 280,000 or more civilians were trapped in the fighting. ${ }^{26}$ The government has denied that it killed civilians during the final stages of the war. ${ }^{27}$ It also described the U.N. panel of experts as "an unwarranted and unnecessary interference with a sovereign nation." Media reports indicate that there is little prospect that the government of Sri Lanka will hold anyone accountable for war crimes because of the involvement of top government figures.

U.N. Secretary General Ban Ki-moon has also reportedly taken the position that he alone does not have the authority to establish an independent mechanism to investigate alleged violations of international humanitarian and human rights law in Sri Lanka as recommended by the U.N. panel. Such a mechanism, he argues, would require either the consent of Sri Lanka or an international body such as the Security Council or the General Assembly. ${ }^{28}$ The U.N. High Commissioner for Human Rights has called for a "fully fledged international inquiry" and added that she thought the panel's report would shock the international community into finally taking action. ${ }^{29}$ Sri Lanka has stated that it does not consider the report an official U.N. report. Sri Lanka is not a member of the International Criminal Court (ICC). Thus, the Security Council would have to request the ICC to investigate war crimes in Sri Lanka. Russia and China, as permanent members, have veto power in the Security Council and are thought to oppose formal Security Council involvement in the matter. $^{30}$

The Lessons Learnt and Reconciliation Commission (LLRC), appointed by the Sri Lankan government to recommend measures for post-war reconciliation, published its much-anticipated report in December 2011. ${ }^{31}$. Sri Lanka established its own LLRC, which has been described as lacking credibility or impartiality. ${ }^{32}$.For the LLRC's recommendations in relation to the allegations of serious violations of international humanitarian and human rights law, against both the Sri Lankan military and the LTTE, do not set out clear measures to ensure the criminal accountability of perpetrators.

However, what surprised many were the LLRC's observations about democracy, citizenship, fundamental rights, the rule of law, good governance, creeping militarisation, and governmentsanctioned criminal activity. At least with regard to those observations, the robustness of the Commission's recommendations was not widely expected, even if neither its analyses nor the recommendations themselves are beyond informed critique. The report accordingly received a cautious welcome from local civil society and the international community. ${ }^{33}$ (CPA Report 2011) While they were disappointed that the LLRC had not been sufficiently rigorous and forceful in regard to criminal accountability, and while aware of policy alternatives that the LLRC chose not to adopt, these responses rightly stressed that the success of the reconciliation process would depend significantly on the government's sincerity and seriousness of purpose in implementing the LLRC's recommendations in full.

Many international and national observers stated that the LLRC did not adequately address accountability for alleged war crimes committed by the government and the LTTE during the final months of the conflict. The LLRC report acknowledged that hospitals were shelled and that there were considerable civilian casualties during the final stage of the conflict and recommended investigations into "possible implications of the security forces" in specific instances of civilian death or injury. Prominent international NGOs, however, stated that the LLRC report exonerated

\footnotetext{
${ }^{26}$ Joe Lauria, "Sri Lanka War Crimes Claims Credible," The Wall Street Journal, April 26, 2011.

27 "World Report Sri Lanka," Human Rights Watch, http://www.hrw.org. \{Accessed on 4/4/2013\}

28 "UN Chief Says Can't Order Probe into Sri Lanka War," Reuters, April 25, 2011

${ }^{29}$ Catherine Washington, "War Crimes Inquiry Only Hope of Justice for Victims," The Times, April 27, 2011

30 "Sri Lanka Rejects UN War Crimes Report, Calls it Unofficial," Reuters, April 26, 2011.

31 The Report of the Commission of Inquiry on Lessons Learnt and Reconciliation (2011), available at:http://groundviews.org/wp-content/uploads/2011/12/FINAL-LLRC-REPORT.pdf\{Accessed on 4/4/2013\}

32 "UN Panel on Sri Lanka Delivers Report," Aljazeera, April 12, 2011

${ }^{33}$ Centre for Policy Alternatives (2011) Release of the Lessons Learnt and Reconciliation Commission (LLRC) Report, available at: http://cpalanka.org/release-of-the-lessons-learnt-and-reconciliationcommission-llrc-report/\{Accessed on 2/4/2013\}
} 
the government of any wrongdoing. They noted that the report found no systematic government wrongdoing on issues such as the "white flag" incident of the alleged killing of surrendering LTTE fighters, extensive shelling of No Fire Zones, systematic shelling of hospitals, and the withholding of humanitarian supplies from civilians entrapped by the LTTE. The report also limited its analysis of the Channel 4's "Sri Lanka's Killing Fields," which contains video footage of purported Sri Lankan soldiers executing bound prisoners and making lewd comments while mishandling partially clothed female bodies, to a technical discussion of the video's authenticity. ${ }^{34}$

\section{UNHRC and Sri Lanka}

The United Nations Human Rights Council (UNHRC) is an inter-governmental body within the UN system responsible for strengthening the promotion and protection of human rights around the world, as well as addressing situations of human rights violations and making recommendations in respect of them. The UNHRC is made up of $47 \mathrm{UN}$ member states elected by the UN General Assembly in New York. The UNHRC is based in Geneva.

Since the Human Rights Council adopted a resolution at its March 2012 session calling for action, the Sri Lankan government has taken no significant steps to provide justice for victims of abuse and accountability for those responsible for war crimes and violations of human rights in the country. Instead, over the last year, the Sri Lankan government has continued its assault on civil society, human rights defenders and media. Rather than making substantive moves toward ending impunity and supporting rule of law, the Sri Lankan government has opted for cynical gestures designed to keep the international community at bay. The latest attack was on the independence of the judiciary, in which the Rajapaksa administration orchestrated the impeachment of the chief justice after she ruled a government-sponsored bill to be unconstitutional. The administration replaced her with a political ally of the government with a long record of rejecting accountability for rights abuses.

The UN Office of the High Commissioner for Human Rights has recognized this state of affairs in its report on Sri Lanka to this session of the Council and called for an independent and credible international investigation into alleged violations of international human rights and humanitarian law. The report echoed the findings of the UN Panel of Experts report of April 2011 which also called for such an investigation.

The government has taken no significant steps to investigate the numerous and credible allegations of war crimes and other serious human rights abuses committed by government forces and the (LTTE) during the armed conflict that ended in 2009, which have been documented by the UN and other independent organizations such as Human Rights Watch, the International Crisis Group and Amnesty International. The authorities have not reported any criminal prosecutions for serious rights abuses committed during the final years of the conflict. Indeed, thus far impunity for these abuses has been total. Most disturbingly, an army court of inquiry set up by the government to look into these allegations issued a report on February 15 which fully exonerated the army from any liability for civilian casualties.

The Sri Lankan government's failure to hold its forces accountable for serious abuses, its persistent denial that its forces committed any war crimes, the lack of concrete action following the establishment of numerous commissions, and the military court of inquiry's recent decision to exonerate the military of any responsibility for war crimes make it clear that neither the Sri Lankan people nor the international community can rely on Sri Lankan government processes to adequately investigate the allegations. In light of this, Human Rights Watch urges the Council to establish an international independent investigation to probe all allegations and respond once and for all to the world's call for action.

The United States has circulated a proposed resolution against Sri Lanka at the UNHRC in March 2013. A documentary by Britain's Channel 4 (No War Zone - the Killing Fields of Sri

34 /http://asiantribune.com/news/2012/05/25/us-human-rights-report-2011-sri-lanka-lack-accountability-war-crimeshighlighted. \{Accessed on 2/4/2013 
Lanka) is to be screened at the UNHRC. This documentary is a follow-up to two earlier documentaries by the same channel. The first, titled Sri Lanka's Killing Fields (June 2011), containing particularly shocking footage of war crimes, was screened at gatherings of representatives of different countries. The second, Killing Fields: War Crimes Unpunished (March 2012) systematically presented the evidence of the Sri Lankan government's war crimes. An advance screening of the latest film was held at Delhi on February 2. In the words of the director of the film, "The new evidence in the film is certain to increase pressure on the Indian government not only to support a resolution on Sri Lanka and accountability, but also to ensure that it is robustly worded, and that it outlines an effective plan for international action to end impunity in Sri Lanka." 35

Addressing the media following the adoption of the resolution, the U.S. Ambassador Eileen Donahoe said the resolution should be seen as both an expression of support by the international community to the people of Sri Lanka, and as an expression of encouragement and concern to the government of Sri Lanka. Donahoe said."The international community came together to call upon the government of Sri Lanka to fulfill its stated obligation to its own people to take concrete steps to move forward to address outstanding issues related to truth and reconciliation, and by meeting its obligation on accountability," .

The Sri Lankan government has done little so far to address the decades-old challenge of developing a set of political reforms able to address the grievances of Tamils and other minorities. A central test of the government's commitment to finding a lasting and just peace will be its willingness to implement provisions in the existing constitution granting powers to provincial councils. In a fair process of negotiation, the government may well have to go further and consider additional legal changes likely to be necessary to satisfy representatives of Tamils, Muslims and other minorities. To date, though, the Rajapaksa government has yet to initiate any political reforms or process of negotiation with Tamil and other minority leaders.

\section{POST RESOLUTION SCENARIO}

The UNHRC resolution highlights past and ongoing human rights violations in Sri Lanka, but regrettably fails to establish an independent and international investigation into alleged crimes under international law, Amnesty International said. While the continued inclusion of Sri Lanka on the Council's agenda is an important step, the Council failed to call for an independent, international investigation into war crimes and other serious human rights abuses committed by the LTTE and government forces during the last phase of the war. "However, it is regrettable that the resolution fails to establish an independent and international investigation into the armed conflict and alleged crimes under international law by both the government and the Tamil Tigers.

The Government, some political actors and civil society groups have criticized and opposed the resolution as being an attempt to intervene in the domestic affairs of Sri Lanka. Furthermore, there were some who stated that the Government has taken numerous measures to address human rights, peace and reconciliation and that outside involvement would negatively impact the steps taken so far. The resolution does not contain provisions providing for external interference in the domestic affairs of Sri Lanka. Instead, it has provisions to support the Government of Sri Lanka to fulfill its obligations. The resolution provides for the support of the UNHRC, other member states.

Following the adoption of a second resolution on Sri Lanka at the (UNHRC) in Geneva, the US stated that the international mechanisms can be appropriate in cases where states are either unable or unwilling to meet their obligations. Speaking in a press conference, US Ambassador to Sri Lanka, Michele Sisson said that the international community is committed to discussing post Geneva situation in building international consensus on the most practical way forward and one of those ways forward articulated at the UNHRC in the resolution on a comment by the US Ambassador to Geneva was looking for a constructive role of the Office of the High Commission of Human Rights. "The expectation is that the government of Sri Lanka heard this message coming

\footnotetext{
${ }^{35}$ http://www.newlankasri.com/ta/link-3m4240Sd6gb6eEKcQ373.html. \{Accessed on 29/3/2013
} 
from a broad cross section," Sisson said, adding that the countries that the 40 plus countries that cosponsored the resolution and those who voted in favour of it were looking at the constructive role of the office of the High Commission for Human Rights to continue to report on these issues. When asked whether the US believed that the government of Sri Lanka would implement the recommendations in the report of the Office of the High Commissioner for Human Rights given the critical comments made against Navi Pillay and her office by Sri Lanka, Sisson told The Sunday Leader that the resolution has given a strong message with "a majority of the Council sitting and saying yes to a resolution that shows appreciation to the efforts by the High Commissioner and her office. $^{36}$

Pro-government commentators criticized the resolution and they said that, The American sponsored resolution adopted at the UNHRC sessions in Geneva was the sum of double standards, political opportunism and muddled diplomacy. Double standards were the American contribution. While unmanned American aircraft are still massacring terrorists as well as innocent men, women and children in the remote borders between Afghanistan and Pakistan, American and other western diplomats with much gravitas demanded the 'accountability' and 'meaningful action' on the part of the Sri Lankan government in what happened in a bloody conflict that ended four years ago. All cries of human rights violations being home grown in the American back garden, fell on deaf ears, as usual. ${ }^{37}$

There is value in new prospects for mutual development and prosperity, and it is imperative that the U.S and Sri Lanka consider a broad engagement strategy to take advantage of these opportunities. Sri Lanka is well positioned to build on its 200 -year-old trade partnership with the U.S and become a stronger geopolitical and strategic ally in the decades to come.

Amnesty International's Sri Lanka expert Yolanda Foster said that the UN Member States have sent a clear signal to the Sri Lankan government that crimes of the past cannot simply be ignored, but need to be investigated and the perpetrators brought to justice. The text also crucially highlighted the still very worrying human rights situation in Sri Lanka today, and called for regular UN reporting on the implementation of the resolution, including of ongoing human rights violations. ${ }^{38}$

After the second resolution US- Sri Lanka relation paved the way for low edge and the Sri Lankan government refused to take technical support fund provided by the US government to upgrade judicial system in Sri Lanka that amount of money nearly 400 million US dollars. And also Sri Lanka government cancelled MOU between Trincomale urban council and US embassy on regarding to establishing American information center at the council. And Sri Lanka boost up its relation with China and build strategic cooperation with China during recent visit of Sri Lanka president to China and China is the leading country to financially helping to Sri Lanka.

According to news reports, President Mahinda Rajapaksa lambasted the US-backed resolution at the UN Human Rights Council against his country, and said that such "attacks would not defeat or intimidate" Sri Lanka. "This attack would not surprise us at all. These attacks would not subdue us either, nor would they defeat or intimidate us in any way" he added....He also termed all allegations against his Government as "false accusations with ulterior motives".

\section{CONCLUSION}

The civil war ended in 2009 but four years later the country has yet to find its path of reconciliation and to heal the wounds of war. At the present time it also appears that Sri Lanka is moving backwards, and not forwards, in terms of securing the rule of law and reconciliation. This has impacted negatively on the rule of law and by extension the protection of human rights and political accountability. There is also the rise of inter-religious tensions fanned by government allies. A new dimension of inter-communal unrest is the rise of Buddhist extremism in some

\footnotetext{
${ }^{36}$ ( http://www.newlankasri.com/ta/link-33I6C3323S.html. \{Accessed on 29/3/2013\}.

${ }^{37}$ Sunday leader 24/3/2013.

${ }^{38}$ Sunday leader, $24 / 3 / 2013$
} 
quarters; it has targeted the Muslim community and taken on an open and frontal confrontational approach.

One of the main elements of external intervention in the internal affairs of post-war Sri Lanka is the continuing pressure being brought to bear on the government to adopt a system of provincebased devolution as one of the instrumentalities of ethnic reconciliation. It is, indeed, unfortunate that the LLRC itself has made a similar prescription. There is no evidence in the voluminous report produced by the Commission that it made any attempt to draw 'lessons' relevant to the subject of territorial devolution and sub-national inter-group conflict from our own experiences, leave alone the abundance of international experiences. Its recommendation, however, has had the effect of legitimizing the demand made by the global west which, in earlier times, was so obviously based on a nakedly superficial, local NGO-nurtured, understanding of Sri Lankan affairs.

Indeed this pressure is difficult to circumvent or surmount, given Sri Lanka's dependence on aid and trade. Yet, one cannot overstate the importance of Sri Lanka, pursuing an independently charted course in matters pertaining to internal and external affairs. It is a vital necessity that could be achieved by the present regime which, despite its shortcomings, has demonstrated extraordinary strength in acting on the basis of its own convictions while continuing to enjoy an unprecedented level of popular support. If Sri Lanka succumbs now, it is unlikely that the prevailing circumstances would recur in the foreseeable future.

It must also be remembered that the two thematic concerns of the present external interventions specifically focused on post-war affairs - 'reconciliation' and 'accountability' - are not interrelated in the sense that whatever progress Sri Lanka makes towards reconciliation (there could be no denial that tangible progress has already been made), the demand for accountability (for 'war crimes' and 'crimes against humanity' allegedly committed by the government during the concluding phase of the war) will remain, probably with increasing vehemence. This, is primarily because the segments of the minorities that has continued to be committed to the mission of dismantling the Sri Lankan nation-state, and has thus provided the main impulses for external intervention, will persist with their desire to make martyrs of the criminals who perished in midMay 2009 and vent their fury at those who brought about that debacle, but remain hostile to any possible 'reconciliation' outcome of a future Northern Provincial Council. To them and their allies within and outside Sri Lanka - the latter includes governments hostile to the Rajapaksa regime that have already established an abnormal 'diplomatic' tradition of maintaining direct contact with elements pledged to destabilize the elected government of the country. ${ }^{39}$

The United States too has important interests in play. One that has risen in importance in the last two decades is the strategic importance of the Indian Ocean, which is not just a passageway between the major U.S. security presence in the Persian Gulf and in the Western Pacific. It has become a strategic zone in its own right, and the United States needs to engage with Sri Lanka on that basis.

Sri Lanka's relations with the United States have always been influenced by the human side of the government's actions. From the time of independence, Sri Lanka was a country that held free elections and took pride in its ability to bring about peaceful governmental change. It was and is a country where everyone can read, nearly everyone finishes secondary school, and basic health care is the envy of the region. These are accomplishments that have brought the United States and Sri Lanka together. On the other hand, the ethnic war and the JVP uprising created a terrible legacy of disappearances and political violence that left thousands dead in Sri Lanka - and did terrible damage to U.S.-Sri Lankan relations in earlier years.

Human rights represent an important strand in America's political makeup, one that has tremendous resonance around the United States. Americans share in the excitement of countries that are recovering from long internal conflicts. Look at the way the opening of the political system in Myanmar has captured people's imagination. Sri Lanka has an opportunity to generate that same

\footnotetext{
${ }^{39}$ Island 23/5/2013.
} 
kind of positive excitement, using a mechanism it created, and serving a goal - the creation of a more united country - that all its politicians espouse.

Sri Lanka is going to likely be watched closely by the international community for how it handles human rights and war crimes issues related to the end of the war and for how it handles its reconciliation with its minority. The international community may also be increasingly interested in the role that Sri Lanka may play in the evolving geopolitics of the Indian Ocean region.

Sri Lanka could have been a very different country today. There is a need to recognize that although the civil war ended in 2009 the country has yet to find its path of reconciliation through an inclusive process of political negotiations and a sincere effort to heal the wounds of war. This would have been a commemoration that all Sri Lankans, respecting multi ethnicity, equal rights, and the safety and dignity of all, could have taken part in as a united Sri Lankan nation.

The actions of the Rajapaksa government have not yet addressed the long-standing concerns of the international community. Following the adoption of the second US backed resolution on Sri Lanka at the UNHRC in March 2013, the US has been engaged in monitoring the progress made by the Rajapaksa government in implementing the clauses of the resolution and honoring its commitments made before the international community. Representatives of the US government have been in constant contact with political parties as well as members of the civil society to monitor the government's progress. Political commentators learns that the US is so far displeased that the Rajapaksa government has not shown any progress in moving forward even in the implementation of the recommendations in the LLRC.

Successfully addressing the LLRC recommendation in Sri Lanka could go long way towards ensuring a smooth post-war transition and contribute toward building cordial relations with world power especially with USA on tolerance and mutual understanding. Alternatively, a failure on a part of the Government regarding to the second resolution to confront tension with the USA could lead to consequences such as economic sanctions, travel bans, international investigations etc.

\section{References}

[1] http://www.newlankasri.com/ta/link-33I6C3323S.html. \{Accessed on 29/3/2013\}.

[2] http://www.newlankasri.com/ta/link-3m4240Sd6gb6eEKcQ373.html. \{Accessed on 29/3/2013\}

[3] The Report of the Commission of Inquiry on Lessons Learnt and Reconciliation (2011), available at:

http://groundviews.org/wp-content/uploads/2011/12/FINAL-LLRC-REPORT.pdf \{Accessed on $4 / 4 / 2013\}$

[4] “UN Panel on Sri Lanka Delivers Report,” Aljazeera, April 12, 2011

[5] Centre for Policy Alternatives (2011) Release of the Lessons Learnt and Reconciliation Commission (LLRC) Report, available at: http://cpalanka.org/release-of-the-lessons-learntand-reconciliationcommission-1lrc-report/ \{Accessed on 2/4/2013\}

[6] Report of the Secretary-General's Panel of Experts on Accountability in Sri Lanka, March 31, 2011

[7] Joe Lauria, "Sri Lanka War Crimes Claims Credible," The Wall Street Journal, April 26, 2011.

[8] "World Report Sri Lanka," Human Rights Watch, http://www.hrw.org. \{Accessed on $4 / 4 / 2013\}$

[9] “UN Chief Says Can’t Order Probe into Sri Lanka War,” Reuters, April 25, 2011

[10] Catherine Washington, "War Crimes Inquiry Only Hope of Justice for Victims," The Times, April 27, 2011 
[11] “Sri Lanka Rejects UN War Crimes Report, Calls it Unofficial,” Reuters, April 26, 2011.

[12] “US Wants Sri Lanka to Act First on Wartime Rights Violations," Reuters, May 4, 2011.

[13] U.S. Department of State, Congressional Budget Justification for Foreign Operations, FY2012, Annex: Regional Perspectives

[14] "Another bead in the 'String of Pearls'? Interpreting Sri Lanka's Foreign Policy Realignment", Sergei De Silva-Ranasinghe, China Security, Issue 19, 2011, World Security Institute,

http://www.chinasecurity.us/index.php?option=com_content\&view=article\&id=492\&Itemid= 8. $\{$ Accessed on $1 / 4 / 2013\}$

[15] http://www.gpo.gov/fdsys/pkg/CPRT-111SPRT53866/html/CPRT-111SPRT53866.htm. accessed on $23 / 3 / 2013$

[16] /http://asiantribune.com/news/2012/05/25/us-human-rights-report-2011-sri-lanka-lackaccountability-war-crimes-highlighted. $\{$ Accessed on 25/4/2013\}

[17] "Another bead in the 'String of Pearls'? Interpreting Sri Lanka's Foreign Policy Realignment", Sergei De Silva-Ranasinghe, China, Security, Issue19, 2011, World Security Institute,http://www.chinasecurity.us/index.php?option=com_content\&view=article\&id=492 \&Itemid $=8\{$.Accessed on $29 / 4 / 2013\}$

[18] Report to the Congress of the US-China Economic and Security Review Commission, 2005, $\mathrm{p}$. 171, http://origin.www.uscc.gov/sites/default/files/annual_reports/2005-Report-toCongress.pdf $\{$ Accessed on 28/3/2013\}

[19] Report to the Congress of the US-China Economic and Security Review Commission, 2012, p. 17 , http://origin.www.uscc.gov/sites/default/files/annual_reports/2012-Report-to-Congress.pdf. Accessed on 26/3/2013

[20] Cited in http://www.gpo.gov/fdsys/pkg/CPRT-111SPRT53866/html/CPRT-111SPRT53866.htm. Accessed on 27/3/2013

[21] "String of Pearls: Meeting the Challenge of China's Rising Power across the Asian Littoral", Christopher J. Pehrson, 2006, Strategic Studies Institute (US). http://www.strategicstudiesinstitute.army.mil/pdffiles/pub721.pdf \{Accessed on 30/3/2013\}

[22] Sujan Dutta, "USA, India Engaging with Sri Lanka Amid Growing China Role," BBC News, March 11, 2009. \{Accessed on 23/4/2013 \}

[23] Michael Richardson, "Full Steam Ahead for Naval Might," The Straits Times, January 15, 2009.

[24] "Chinese Billions Helping Lanka Ward Off Western Peace Efforts," Asian News International, May 2, 2009

[25] /http://www.crisisgroup.org/en/regions/asia/south-asia/sri-lanka/191-war-crimes-in-srilanka.aspx. accessed on 11/05/2013

[26] Jain: Rashmi, US-Pak Relations, 1947-83, Radian Pub, New Delhi, 1983.

[27] Pervaiz Iqbal Cheema, 'American Policy in South Asia: Interests and Objectives', in Stephen Cohan(ed), The Security of South Asia: American and Asian Perspectives, Vistaar Pub, New Delhi, 1987.

[28] A.Subramayam Raju, Democracies at Loggerheads: Security Aspects of US- India Relations, South Asian Pub, New Delhi, 2001. 
[29] Gupta,R.C., US Policy Towards India and Pakistan, B.R.Pub, New Delhi, 1977.

[30] /http://www.crisisgroup.org/en/publication-type/key-issues/research-resources/conflicthistories/sri-lanka.aspx. accessed on 11/5/13

[31] Jayawardena, Kumari - "The Rise of the Labour Movement in Ceylon", Durham, N.C., 1972. - "Ethnic and Class Conflicts in Sri Lanka", Colombo, 1986. 